James Coburn

Høgskolen i Hedmark

\title{
Comparing varieties of in-service English Language Training for primary school teachers in Norway
}

\begin{abstract}
International trends show the formal teaching of English starting at an increasingly early age. This presents challenges for national education systems and in particular, for primary schools and for primary school teachers who are not necessarily trained as English teachers. The present study investigates two different ways of organising and designing in-service educational training (INSET) in Norway for those primary school teachers who currently teach English without any formal training as language teachers. One response is a nationally organised programme; the other, a local initiative. The different course contexts are first outlined, and then the course designs are presented using document analysis interspersed with extracts from interviews with teacher trainers. Teachers' perceptions of some course outcomes are presented. Central themes arising from the comparison are discussed; including the need to organise collaborative learning environments to sustain English subject teacher development, the role which teacher trainers play in fostering change, and the question of what is appropriate subject matter and methodology for INSET courses. The study concludes that a more comprehensive and coherent system of in-service training is required towards 2030. Proposals include short language immersion courses, the training of teachers-as-trainers, and the systematic introduction of networks of primary school English subject teachers to nurture professional development.
\end{abstract}

\section{Introduction}

The growing importance of the English language is reflected in the tendency for national school systems to start teaching English from an increasingly early age (Eurydice 2012; Enever 2011). In Norway, this trend means that large numbers of primary school teachers now teach English to children on a regular basis without formal qualifications or preparation. This is because English has never been an obligatory part of any teacher training for Norwegian primary school teachers, despite English long being taught from year 1 in primary school, and having status as a "basic" subject in official educational documents. The situation is similar in Denmark, though, in contrast, in Sweden and Finland, English is a compulsory part of the primary school teacher training. 
According to the Norwegian Ministry for Education and Research, approximately 42000 teachers currently work in primary schools in Norway. A report from Statistics Norway (Lagerstrøm 2007) tells us that approximately $70 \%$ of teachers who teach English in years 1-4 had no formal competence in the language, while just over 50\% of those teaching English in years 5-7 were without formal competence. Lagerstrøm (2007) also reported that a higher proportion of older teachers had formal competence in English in 2005. Since some of these teachers have now retired the percentage of teachers without formal competence has been increasing. In other words, it is safe to say that many thousands of primary school teachers in Norway currently teach English without formal competence in the subject.

\section{The organisation of in-service training}

This paper focuses on three courses within two different models of organisational partnership for professional development (Villegas-Reimers 2003). Nearly all of the teachers taking the courses are experienced English teachers in Norwegian primary schools. The first two courses award 30 ECTS (European Credit Transfer System) points, and are within the framework of the Norwegian "Competence for Quality" (KK henceforth) programme. This started up in 2009 as an inter-institutional collaboration between the Ministry for Education and Research, the Norwegian Association of Local and Regional Authorities (NALRA), and selected universities and university colleges that were paid to offer the courses. The second model is a 15 ECTS course organised wholly independently of the KK program, a cooperative effort between one local municipality in a rural county and the regional university college closest to the municipality. All courses are hereafter referred to as in-service educational training (INSET) courses.

\section{Background for the comparison between the KK courses and the local course}

The KK program is financed jointly by the Ministry for Education and Research (henceforth MER), together with local municipalities who select which teachers to send on the courses. However, a significant number of local municipalities, especially those in rural areas which use considerably more of their own money on in-service training per teacher than urban municipalities (MER report 2012, p.13), disagree with the way that all municipalities have been forced to share the costs of what is perceived as a centralised program (Mellegård, 2010; telephone conversation with Hans-Olav Gammelrud, advisor for NALRA). The main cause of the expense of the KK program is the cost of hiring in substitute teachers, something which locally organised INSET courses avoid by carefully organising the school classes for the teachers attending the courses based on two-teacher systems, so that on the one or two days a month that teachers are absent, it is not necessary to hire in extra teachers. 
In the school year 2012-2013, the regional university college in the county of Sogn og Fjordane, which regularly provides local-regional INSET courses, was asked by a rural municipality to provide a decentralised course for local primary school teachers. This course was chosen as the object of research and is compared with two KK courses. It is henceforth referred to as the local course.

The MER has ordered different evaluation reports on the KK (e.g. Oxford Research 2012, Nordic Institute for studies of Innovation, Research and Education (NIFU) 2013), but these have been constrained by a limited mandate. The reports have, for example, not commented on the fact that the KK programme trains only approximately one hundred primary school teachers a year as English teachers while many thousands continue to teach English without formal competence. The research in this paper therefore aims to shed light on other possibilities, seeking to find answers to the following research question:

What characterises the differences in organisation, pedagogical design, evaluation and perceived outcomes of the KK course model vis-à-vis the local model?

\section{Literature review: INSET research and course design}

A recent British Council report summarising a wide variety of research suggests that

the key to successful INSET is the integration of two main 'dimensions', viz., i) course-based vs school-based teacher learning opportunities, and ii) educational system vs school system priorities (Waters \& Vilches 2010, p.4)

In other words, course-based theoretical learning needs to be closely linked to practical understanding through classroom work; while the overall management of educational systems, including institutions responsible for teacher training, needs to be effectively linked to and integrated with local level school systems. The report also gives recommendations for best practice, emphasising the need to provide INSET follow-up through "active and extensive educational and school support”. According to Mujis and Linday's (2008) summary of empirical research in continuing professional development, such support should include the creation of collaborative professional learning environments for teachers since they represent the "single most important factor" to enhance teaching and learning.

A theoretically-grounded overview of international INSET research (Hayes \& Chang 2012) gives examples of countries with 'networks of in-service training centres which are staffed either on a full or part-time basis by teachers seconded from schools" in which the "teachers-as-trainers have greater face 
validity than university or college based trainers” (2012, p.116). In comparison, in most countries, teacher educators are typically "academically well-qualified college or university lecturers with high status but limited or outdated practical classroom experience" (2012, p.112). The question of what kind of educational background and experience teacher trainers should have is an important topic of debate (Jordenais 2011), intimately connected to the question of course content or subject matter.

Until the 1980s, the knowledge needed for teaching was understood to equate to the subject matter, and in language teacher training this subject matter came to be compartmentalised into a "two-part" knowledge base (Graves 2009, p.117). One part comprised grammar and phonetics along with cultural and literary knowledge, the other part a methodology - skills component. However, the conceptual framework of language teaching pedagogy and course design has since been expanded to take greater account of "the activity of teaching itself (...) the contexts in which it is done and the pedagogy by which it is done" (Johnson \& Freeman 1998, p.397). Thus, teacher training methodology and knowledge needs to be selected and constructed with careful reference to specific teaching environments and needs.

The design of language teaching courses is complicated by the fact that the subject matter is not simply equivalent to the content of the subject as it might be in other subjects, because this subject matter is at the same time the medium through which the subject is taught (see Borg 2006). This means that plentiful exposure to the language is essential and developing the teacher's own target language proficiency is of crucial importance. Though the extent to which nonnative English-speaking teachers need to teach through the medium of the target language is a complex and controversial issue (Kamhi-Stein 2009, Hall \& Cook 2013), there is no doubt that the teachers' own level of language proficiency is important, as the following primary school research indicates:

even if students' had spent the first three school years with a teacher who taught around $80 \%$ of the lessons in the target language, their oral development and their confidence for communicating decreased noticeably after only four months with a new teacher who only used the target language for around $30 \%$ during the language lessons. When teachers frequently use translation between L1 and L2, students seem to copy the communication pattern and use L1 instead of L2 whenever possible and loudly crave translations even if they would be able to understand by concentrating and making use of their guessing competence. (Lundberg 2012, pp.3-4)

In addition to focusing on the importance of developing speaking proficiency, INSET course design needs to take account of the fact that research into teachers of young learners (Burns \& Copland \& Garton 2011) suggests that developing teachers' confidence may be as important as developing language proficiency. This implies that if new and better approaches to language teaching are to be introduced, teacher trainers need to engage in collaborative processes with 
teachers in order to build their confidence. An equally important aspect of this collaboration is to assist teachers to become more aware of their own beliefs about language teaching since they need "to recognise their existing knowledge and beliefs in order to transform them” (Graves 2009, p.118).

\section{Method}

The goal of this study is to compare the organisation and pedagogical design of three different INSET courses. It is primarily qualitative in nature, though some quantitative data are also presented. Data sources are documents (e.g. course descriptions, evaluations and reports on the KK program; and historical documents relating to Norwegian INSET policy from 1997-2006), semistructured interviews with teacher trainers, open-ended interviews with educational administrators and teachers' end of course evaluations.

Semi-structured interviews were conducted with eight teacher trainers at the three different course institutions. Using the formal course descriptions as a starting point, questions attempted to elicit teacher trainers' views on the chosen knowledge base, approaches to language teacher training, and the relation between theory and practice.

Open-ended interviews were conducted with the headmaster at the primary school which hosted the local course, the Head of Schools in the local municipality, and the Dean at the regional university college which supplied the teacher trainers for the local course. Due to space limitations these open interviews are only briefly referred to.

The diversity of viewpoints and data from the various data sources strengthens the quality and validity of the research (Flick 2007), as does the transparency obtained through peer-checking with the teacher trainers who were asked to read the draft article.

\section{Participants}

The teacher evaluation of the local course was based on a questionnaire filled out by all eighteen teachers who completed the course. Two questions from this questionnaire were also given to all thirty-six participants on one of the KK courses (2013-2014) as it neared completion. This was done to allow a direct comparison to be made between teachers' perceptions of their language skill development on the local course and on one of the KK courses. This direct comparison of course outcomes is limited to a simple presentation of average frequencies in answers given to the two identical questions.

The samples for the two different courses where the direct comparison was made were very similar in terms of teachers' average number of years of teaching experience (11 vs 13 ) and English teaching experience (5 vs 6 ). There were however some differences in teachers' qualifications: Four of the eighteen 
teachers on the local course already had 30 ECTS points in English while only one of the thirty-six teachers on the KK course had 30 ECST points.

Otherwise, for the KK courses, the only evaluation material available consisted of more general data in reports gathered centrally, first by Oxford Research and then by NIFU on behalf of the MER. Unfortunately, NIFU did not have permission from participants to make more detailed data available to independent researchers.

\section{Researcher's stance}

Although the MER has ordered regular reports and evaluations of the KK program, educational evaluations conducted for clients are often "not designed to speak to the underlying (...) policy issue" (Datta 1997, p.351). This is often because "most clients hope to use evaluation findings in advocacy for program continuation" (Stake 1997, p.470).

In contrast to the KK evaluations, this study deliberately introduces two different perspectives on INSET to allow important questions to be raised relevant to the future quality of English teaching in Norwegian primary schools. Motivated by "a search for knowledge" (Cohen et al. 2011, p.49), the research in this paper "actively advocates for the program's target group” (Greene 1995, p.1), those primary school teachers in Norway who teach English without formal competence and would like to upgrade their competence.

\section{Findings}

The findings provide overviews of the KK and local course models, starting with an outline of the organisational frameworks. This is followed by brief descriptions of the pedagogical designs, including teacher trainers' comments explaining the rationale behind significant aspects of the subject matter content, choice of teaching methodology and theory-practice relationship. Short descriptions of teachers' evaluations and perceptions of course outcomes are given after each course model description.

The institutions providing the courses are anonymised as follows: The two courses within the KK program are taught at "City" University (CU) and "Town" University College (TUC), while the local course is taught by the Regional University College (RUC).

\section{Organisation of the models}

The organisation of the educational frameworks for the different course models are shown in Table 1. 
Table 1 The organisation of the different course models

\begin{tabular}{|l|l|l|}
\hline & Competence for Quality (KK) courses & Local course \\
\hline $\begin{array}{l}\text { Partnership } \\
\text { between }\end{array}$ & $\begin{array}{l}\text { MER, Universities and University } \\
\text { Colleges, and willing municipalities }\end{array}$ & $\begin{array}{l}\text { A local municipality and local schools } \\
\text { with the Regional University College }\end{array}$ \\
\hline ECTS points & 30 ECTS & 15 ECTS \\
\hline $\begin{array}{l}\text { Course location } \\
\text { and delivery }\end{array}$ & $\begin{array}{l}\text { Online, but with 5-6 two day seminars at } \\
\text { Universities/ University Colleges }\end{array}$ & All 8 seminars at a local school \\
\hline Seminar hours & $70-80$ hours plus 1 week in York, UK & 32 hours \\
\hline $\begin{array}{l}\text { Teaching activity } \\
\text { between seminars }\end{array}$ & $\begin{array}{l}\text { Recorded mini-lectures, written feedback, } \\
\text { oral feedback by Skype or sound files, a } \\
\text { few discussion forums }\end{array}$ & Information exchange \\
\hline Costs & Approx. NOK 250000 per person & Approx. NOK 250000 for the course \\
\hline Study time & 37.5\% paid leave & $\begin{array}{l}\text { No paid leave. Some normal teacher } \\
\text { preparation time set aside for study }\end{array}$ \\
\hline
\end{tabular}

The courses represent different partnership models and operate under very different financial constraints. The KK courses are part of a well-funded national program while the local course is in a municipality with very limited resources. The KK courses award twice as many ECST points as the local course and offer more than twice as many seminar hours along with more online interaction between seminars. The costs for one participant on the national courses are approximately the same as the costs for the twenty participants on the local course, this because the teachers on the KK courses get 37.5\% paid leave unlike the teachers on the local course.

\section{The pedagogical design of the KK courses}

Both CU and TUC divide their KK courses into two parts which correspond approximately to a division between the development of knowledge about language, and the development of language teaching methods and methodology. While CU has one main teacher who is responsible for the whole course assisted by a specialist linguistics teacher, the TUC course is more clearly divided in two, between a linguistics specialist and a methodology specialist. The CU course outline is shown in Table 2.

Table 2- CU course outline

\begin{tabular}{|l|l|l|l|l|}
\hline Course parts & \multicolumn{1}{|c|}{ Obligatory assignments } & \multicolumn{2}{l|}{ EXAMS } \\
\hline $\begin{array}{l}\text { English language } \\
\text { and teaching } \\
\text { methodology 1 }\end{array}$ & $\begin{array}{l}\text { 3 short written Language assignments and } \\
\text { 3 teaching methodology - classroom assignments } \\
\text { Theoretical paper - Methodology/Language }\end{array}$ & $\begin{array}{l}\text { Written exam } \\
\text { (language } \\
\text { focus) }\end{array}$ & \\
\hline $\begin{array}{l}\text { English language } \\
\text { and teaching } \\
\text { methodology 2 }\end{array}$ & $\begin{array}{l}\text { 2 short answer written Language assignments and } \\
\text { 2 short written teaching methodology assignments } \\
\text { Lesson Study project- classroom research }\end{array}$ & $\begin{array}{l}\text { 10\% } \\
20 \%\end{array}$ & $\begin{array}{l}\text { Written exam } \\
\text { (language } \\
\text { focus) }\end{array}$ & $20 \%$ \\
\hline & \multicolumn{1}{|c|}{ Sum } & $60 \%$ & \multicolumn{1}{c|}{ Sum } & $40 \%$ \\
\hline
\end{tabular}

The CU course has separate but closely integrated assignments for "language" and "teaching methodology". It puts more emphasis on the assessment of teachers' written language proficiency than on oral proficiency. The second part 
of the course is notable for its Lesson Study - classroom research project whereby teachers plan lessons, not knowing who will teach the lesson till the last minute when the teacher is drawn at random. The TTs say that the teachers learn together through the "strong psychological effect" of planning discourse as they are "battling it out".

The TUC course outline is shown in Table 3.

Table 3 - TUC course outline

\begin{tabular}{|l|l|l|l|}
\hline Module & \multicolumn{1}{|c|}{ Obligatory assignments } & \multicolumn{1}{|c|}{ EXAMS } & \\
\hline English in use & $\begin{array}{l}\text { Reflection on your own role as an English teacher. } \\
\text { How to work with pronunciation in the classroom. } \\
\text { How to work with vocabulary in the classroom } \\
\text { Reader-response task }\end{array}$ & Oral exam & $50 \%$ \\
\hline $\begin{array}{l}\text { Teaching and } \\
\text { English }\end{array}$ & $\begin{array}{l}\text { 2 assignments using children's literature (sound file) } \\
\text { 2 classroom assignments based on oral communicative } \\
\text { activity and use of book set; } \\
\text { Teaching material assessment assignment (pairs) }\end{array}$ & $\begin{array}{l}\text { Home written exam } \\
\text { (Teaching focus) }\end{array}$ & $50 \%$ \\
\hline & & \multicolumn{1}{|c|}{ Sum } & $100 \%$ \\
\hline
\end{tabular}

The first part of the TUC course focuses on the teachers' own language development, although the course assignments are linked to classroom practice. It has an oral examination at the end of the first module which focuses on the teachers' oral proficiency. The TT responsible for the second module on the TUC course explained that it emphasises "very practical things - activities which teachers can transfer directly to the classroom". Both modules emphasise extensive reading.

\section{Developing teachers' oral language proficiency}

TTs at both CU and TUC say that teachers have to talk English during the twoday seminars (10-12 days a year) and during a one week trip to York. They have tried different solutions to increase the amount of time teachers spend talking English between seminars, including the use of regular Skype group conversations, but have given this up due to technical challenges and difficulties in gathering teachers at the same time. They had, however, found other solutions which gave teachers a little extra practice. CU uses Skype to give individual oral feedback while at TUC teachers send in sound files to answer two assignments, receiving feedback through the same medium.

\section{Challenging teachers' traditional ways of thinking and teaching}

The TT at TUC who teaches the second part of the course often presents model activities, and then deliberately creates or exploits opportunities which arise in seminars to challenge, for example, the unnecessary use of translation or the use of decontextualized rote learning. In this way, she and the teachers "jointly construct some sessions”. Using a children's book, “Can't you sleep Little Bear”, she asked the teachers: 
What language could we use there? One person says "irregular verbs" - so then we discussed - how could you work with this - what could you do with the irregular verbs in the book? And then we discussed about - you know - do you take the irregular verbs out of their context and learn them by heart Oh yeah - yes of course everybody is doing that - learning five irregular verbs each week - and then I get on my high horse and talk about alternatives to that - the idea of exposure rather than abstraction

At CU, one of the TTs asserted that teachers "often come without any knowledge of how young learners learn a foreign language”, and have a high level of dependence on the textbook, yet they also have a well-developed capacity for reflection due to their own teaching experience. This TT favoured getting teachers to plan and try out lessons based on curriculum learning aims or the more detailed aims in the European Language Portfolio, and then reflect on the results. This encourages teachers "to remove themselves from the textbook in order that they become confident enough to know how to plan an English lesson building on a learning aim”. She explained that "you can then reintroduce the textbook - and suddenly they become very critical to it- then they can begin to use the textbook rather than the textbook using them”.

\section{Teachers' evaluations of the KK courses}

Towards the end of the 2013-14 TUC course, the participants were asked to assess their language skills. The averages of the results are shown in Table 4.

Table 4: Average of TUC course teachers' self-assessed language skills - near the end of the course (Scale of 1-5: 1 - very good; 2 - good; 3 - ok; 4 - poor; 5 - very poor) N=36

\begin{tabular}{|l|l|l|l|l|}
\hline How do you now rate your proficiency in & Reading & Writing & Speaking & Listening \\
\cline { 2 - 5 } the different language skills? & 2.1 & 2.8 & 2.5 & 1.9 \\
\hline
\end{tabular}

The teachers assessed their receptive skills (reading and listening) as stronger. Among the productive skills, speaking ranked stronger than writing. The teachers were also asked to assess the order of improvement of their language skills, as shown in Table 5.

Table 5: Average of teachers' self-assessed improvement in language skills near the end of the course (1- most improved; 2 - next most improved; 3 - third most improved; 4 - least improvement) $N=36$

\begin{tabular}{|l|l|l|l|l|}
\hline Rate your four language skills in order & Reading & Writing & Speaking & Listening \\
\cline { 2 - 6 } of improvement as a result of the course & 2.3 & 2.8 & 2.3 & 2.7 \\
\hline
\end{tabular}

Teachers considered that their reading and speaking had improved most during the course.

Teacher evaluations of the KK INSET courses were otherwise elicited centrally on behalf of MER, through anonymous questionnaires sent to course participants on all the different subject courses, not just the English courses. 
English was one of only three courses singled out by teachers as having been "particularly useful" (Oxford Research 2012, p.21). However, this positive outcome was tempered by a separate general conclusion which pointed out that the lack of contact between the KK courses and the teachers' home schools leads to a lack of "transfer" of what teachers learn to other teachers in their home schools or local environments (NIFO 2013, p.56 ; Oxford Research 2012, p.37).

\section{The pedagogical design of the local course}

Unlike the KK courses which are designed entirely by the teacher trainers, the content of the local course was agreed as a result of negotiation between teacher representatives and the head TT at the RUC responsible for English teaching methodology courses. The teachers wanted a course called "Teaching methods in English", including "differentiation" and "how to teach grammar". Given this extremely practical remit and her own overfull schedule, the experienced head TT at RUC asked a local primary school English teacher to assist her as a TT. This teacher also has a small (10\%) position as coordinator of a local network for English teachers, though in a different part of the county from where the course was held.

The head TT then designed "a new kind of course" compared with the normal courses at RUC which have the traditional two-part knowledge base division between specialists in linguistics, literature and culture on the one hand, and methods on the other. This new course consisted mainly of language teaching methods and was principally taught by the head TT and the network coordinator, with a few sessions taught by specialists from RUC. Table 6 summarises the local course content:

Table 6: Overview of the 8 four hour sessions - local course content

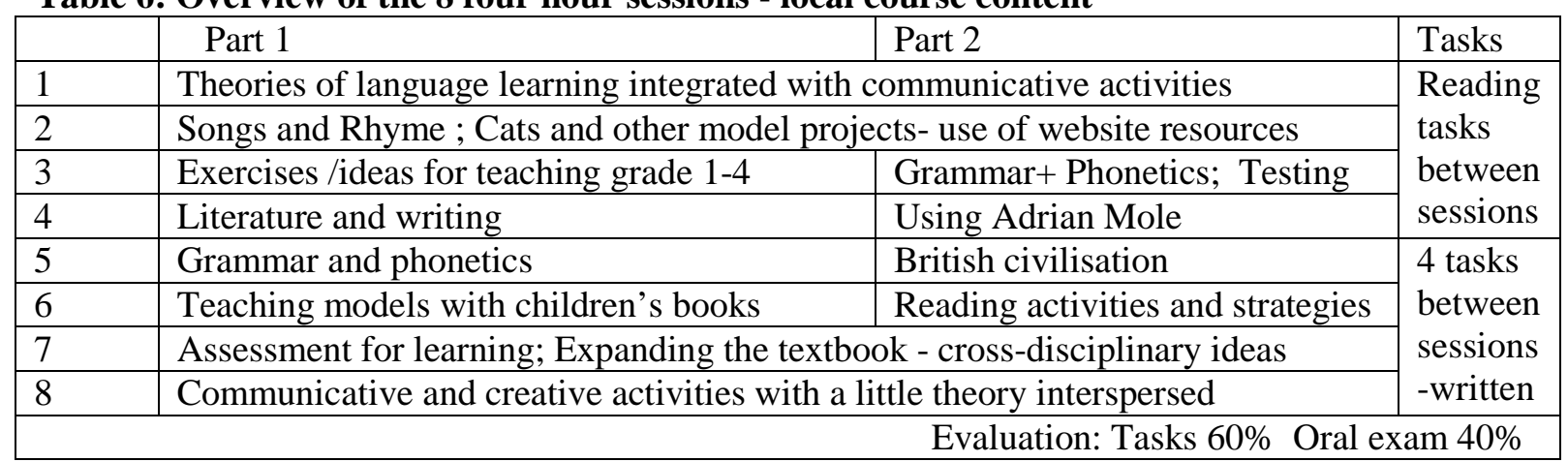

The head TT was determined to ensure that the teachers "should at least understand the basics behind the curriculum", but this was a considerable challenge since, as she noted, the different kinds of communicative competences in the 2006 curriculum are difficult to explain to teachers. This is because they 
don't understand what these are - they are new in relation to what used to define the subject -' 'Lexis and Grammar - so we have to make a huge move - and most teachers don't know about this huge change.

The head TT and the network coordinator provided very practical hands-on activities, ideas, and a variety of generic models such as ways of working with story books including activities "which can be adapted according to themes and characters". The network coordinator showed teachers how they could make their own materials and become less dependent on the textbook. The head TT introduced communicative activities with "short versions of lots of things" while "listening for signals from teachers" because she was "very much in doubt about how much theory to use". She chose to "sprinkle a lot of communicative activities in to illustrate theory" and help the teachers "have fun", "lose their fear" and thereby learn how to use communicative activities in class. Through creative ways of showing how words can be understood in context she introduced "the division into Acquisition and Learning", giving many teachers an "aha! -awakening experience" since they "get to understand that cramming might be a waste of time" since targeted exposure to language in context can be a much more effective and motivating way to widen pupils' vocabulary and learn grammar.

\section{Teacher evaluations of the local course}

Towards the end of the local course, the eighteen teachers were given a questionnaire provided by the researcher which included the same two questions which were later given to the teachers on the TUC KK course (see Tables 4 and 5), asking teachers to assess the current level of their language skills. The average of the results for the eighteen teachers is shown in Table 7.

Table 7: Average of local course teachers' self-assessed language skills - near the end of the course (Scale 1-5: 1 - very good; 2 - good; 3 - ok; 4 - poor; 5 - very poor) $\mathbf{N}=36$

\begin{tabular}{|l|l|l|l|l|}
\hline How do you now rate your proficiency in & Reading & Writing & Speaking & Listening \\
\cline { 2 - 6 } the different language skills? & 2.0 & 2.1 & 2.7 & 2.1 \\
\hline
\end{tabular}

Here, speaking clearly lags behind the other language skills. The teachers were also asked to assess which skills had improved most. The results are shown in Table 8.

Table 8: Average improvement of teachers' language skills near the end of the course (Scale 14: 1- most improved; 2 - next most improved; 3 - third most improved; 4 - least improved) $\mathrm{N}=36$

Rate your four language skills in order of improvement as a result of the course

\begin{tabular}{|l|l|l|l|} 
Reading & Writing & Speaking & Listening \\
\hline 2.2 & 2.3 & 3.0 & 2.5 \\
\hline
\end{tabular}

Teachers perceived that their reading, writing and listening improved most, with speaking least improved.

Otherwise, the responses to the other questions on the local course questionnaire showed that the teachers were in general rather satisfied, 
particularly with the parts of the course taught by the head TT and the "teacheras-trainer”. All the practical tips, ideas, activities, exercises, models, materials and resources were considered the most valuable parts of the course. However, half of the responses considered that the grammar and phonetics sessions, which were taught by a linguistics specialist without experience of training experienced primary school teachers, were set at too high a level.

The evaluations also showed that nearly all the teachers perceived that the course had led to changes in their practices, especially in terms of increased variation. Just over half of the teachers said they had become less dependent on the textbook.

Two of the four teachers who were interviewed expressed clear dissatisfaction with the lack of time they were given to study between the teaching sessions. One teacher explained her decision to participate despite the lack of paid study time, saying: "I don't want to be a teacher who says, sorry no I can't teach English because I'm not good enough. I want to raise my own level”. This teacher's desire for improvement may well represent the aspirations of thousands of other primary school teachers without formal competence in English teaching, and as such forms an important backdrop to the following comparative summary of the findings and answer to the research question.

\section{Comparative summary of the findings}

The research question asked what characterises the educational organisation, pedagogical design, evaluations and perceived outcomes of the KK course model vis-à-vis the local model. The findings show that the financial premises for the organisation of the models are very different: The KK teachers are given paid leave and this allows them to dedicate time to reading in English and also to reflect on new knowledge about language and language teaching methodology, leading to more deeply integrated knowledge. Conversely, the lack of paid study time for the teachers on the local course means that their learning is not likely to be as deeply-rooted.

The design of the local course deliberately emphasizes methods and materials which can be tried out immediately in teachers' practices, bringing together local teachers in a collaborative learning environment. The KK also provides school-based learning opportunities through classroom-based tasks, but the centralised structure of the organisation of the KK courses leads to a focus on individual teachers without contact with teachers' home schools leading to limited knowledge transfer to other teachers.

The choice of subject matter content of the KK and local courses differs most in relation to the amount of knowledge about language which is included. On the local course, the linguistics component was small and was not as well-received as the methodological input provided by the effective partnership between the head TT and the teacher-as-trainer. The KK teachers' evaluations of the linguistics components on their courses are unknown, but some interesting 
related facts did emerge from the interviews with the KK TTs, and these are discussed below.

On the local course, the teachers' perceived weakest language skill, speaking, progressed least. This contrasts with the perceived progress in the development of the TUC course teachers' speaking skills, though even with such development, the TUC teachers' perceived that their speaking proficiency remained much weaker than their receptive language skills.

\section{Discussion}

The results of the comparison of the different course models bring to light a number of important issues. First, neither the KK courses nor the local course are directly connected to any subject teacher networks, plans for local follow-up or long-term professional development. Second, it appears to be the TTs who specialise in methodology who are most likely to act as change agents for the teachers. Third, the research reveals some possible alternatives for the pedagogical design of INSET courses in Norway. Following the discussion of these themes, some implications are outlined in the form of concrete proposals.

\section{The need for collaborative learning environments to sustain learning}

The problem of lack of knowledge transfer to other local teachers which the evaluation reports on the KK program highlight has been recognised in previous INSET research (Waters \& Vilches 2010). One of the TTs pointed out that such transfer is only likely to occur where a particular teacher has a strong position in his or her local school, but even where a teacher does have such a position, research indicates a further problem for the returning KK teachers: If no network-based collaborative learning environment for English teachers exists, case studies from INSET courses without follow-up have shown that participating teachers themselves experience a lack of opportunities for ongoing collaborative development with peers and suggest the need for "(i) a network of like-minded teachers to regularly share and exchange new ideas; and (ii) (...) a mentoring system", because "training alone is not enough" (Ju Youn Sim 2011, p.245).

Unlike the teachers on the KK courses, the teachers on the local course come from the same area with the potential for the development of a collaborative learning network, but also here there is a need for a coordinator or mentors to promote and sustain learning processes. Otherwise, without fresh impulses and opportunities for discourse, teachers' development is likely to stagnate as practical teaching ideas can only be recycled for a limited time. Teachers may then revert to non-communicative language teaching patterns, inappropriate for a modern curriculum. 


\section{The role of the teacher trainers in change and learning}

Even though teacher trainers may know how to initiate processes designed to promote change in teachers' cognitions and practices, this change still takes time, a precious resource. Thus while the both the methodology teachers at TUC and on the local course shared a similar approach to initiating change through their common belief in the usefulness of teaching a variety of generic models; the effects of their efforts were different: The lead TT on the local course felt that time was "a bit short for us to manage to give them enough". She regretted that this led to the teachers being given "fish", but not learning "how to fish". This failure to reach a deeper level of development, together with the inability of the local course to develop teachers' oral proficiency must be seen as the major weaknesses of the local course model.

Change is also influenced by another factor, the background teaching experiences of the different TTs. This appears to influence the degree to which they are able and willing to pro-actively engage in promoting change in teachers' thoughts, beliefs and teaching practices. Thus, the TTs who talked explicitly about how they actively promote change processes were all methodology teachers with considerable previous experience as school teachers. On the local course, the Head TT together with the primary school teacher employed as an assistant TT appeared able to introduce new ideas and methods which were easily acceptable to the teachers, in part because they had high "face validity". Theory suggests that teachers are less resistant to change when they can identify with the innovation they are being asked to make (Fullan \& Hargreaves 1992), and utilising teachers-as-trainers as well as TTs with substantial school teaching experience can thus make it easier for teachers to accept change. In contrast, none of the TTs for the linguistics components on the different courses had primary school language teaching experience, and their teaching was more abstracted from classroom practice. This raises the question as to how and to what extent INSET courses should focus on theoretical linguistics.

\section{Alternative subject matter-knowledge bases and methodology for INSET courses}

The guidelines given by MER to the institutions selected to teach different KK courses specify that part of the course should focus on subject matter knowledge and part on knowledge of subject pedagogy. The TTs on both KK courses use this guidance as part of the justification for including quite substantial linguistics components on their courses, but do not themselves necessarily agree with the guidelines. In particular, the guidelines ignore the fact that for language teachers, unlike in other subjects, it is probably the development of oral language skills proficiency which represents the most important "subject matter knowledge". For example, one of the CU TTs said that if given the choice she would "recommend a pre-course for some teachers to improve their language 
ability - so they have a certain base, so we can focus on their teaching skills rather than their language ability”.

Another of the TTs at CU referred to a possible alternative to the KK course, giving the example of a local-regional 30 ECTS in-service course spread over two years which CU had previously taught before starting the KK program. This course had been ordered by a group of municipalities near CU who requested a focus on language teaching methodology without a separate theoretical linguistics component. According to the TT at CU, the result was a highly successful course using regular teacher classroom experimentation and collaboration as its long-term methodological approach. Teachers experimented with knowledge gained from monthly seminars through practical teaching tasks, which they then wrote up and reflected on together at the next month's seminar. This model reflects current thinking in the international literature about how professional learning for teachers can be effectively supported (e.g. Broad \& Evans 2006).

The experience from the earlier course has influenced the CU KK design which attempts to integrate linguistic content into practical teaching tasks including teaching pronunciation, yet none of the obligatory tasks on the KK course at CU involve experimenting with teaching grammar. At TUC, the TT who concentrates on language development deliberately tries to avoid mixing "how to teach grammar" into sessions where the teachers themselves learn grammar because she feels that it might be "a bit messy" and overload the teachers. The TT also observed that "if you're interested in grammar teaching my impression is that the teachers use their textbooks very slavishly - and follow just what the textbook says and do those exercises and that's it”. This observation implies that it may be particularly challenging to initiate change in this area because the textbooks used by the teachers include certain ways of presenting grammar which the teachers assume are authoritative. On the other hand, due to the linguistics TTs' own lack of school teaching experience, it may also be that they do not feel competent to integrate "how to teach grammar" into their teaching in a way that takes into account the complexity of actual classroom teaching environments. Given the shortage of time and resources on INSET courses, it is therefore debateable as to whether linguistics TTs should be used to teach abstract grammatical knowledge not normally needed in the primary classroom, rather than concentrating resources on developing teachers' oral proficiency, as suggested in the first of the following proposals.

\section{Implications for future INSET courses}

For Norwegian primary school teachers who currently teach English without formal competence or experience of living in an English-speaking country, a supplementary course should be offered in addition to the KK program. This would recognize the special needs of foreign language teachers to be proficient in their main teaching tool, the language. It could be provided in the form of 
tailored two or three week language and methodology courses organised through the Norwegian Study Centre in York, or at selected, monitored language schools in the UK during summer vacations.

Such immersion in the language in a country where the language is spoken is a normal part of studying to be a foreign language teacher in many European countries, though the stay is usually longer. This kind of voluntary course could boost many teachers' English speaking skills, as well as increasing their selfconfidence and motivation. As a voluntary summer course, it would be relatively inexpensive for MER to finance compared with the KK courses, and should not cost teachers anything. Ideally, such courses would be taken immediately before a local-regional INSET course which emphasised school classroom-based assignments, and would be followed up by participation in a local English subject teacher network.

There is an urgent need to systematically develop such networks, thus fostering collaborative learning environments and continuous professional development. These should operate alongside the type of local-regional INSET courses previously taught at CU, providing integrated follow up. Such an approach would accord with recent research which shows that "teaching improves most in collegial settings where common goals are set, curriculum is jointly developed, and expertise is shared"” (Darling-Hammond \& Lieberman 2012, p.150). In addition, a new training for teachers-as-trainers could be devised for selected primary school teachers who already have 60 ECTS in English, preparing them as English subject network coordinators and assistant TTs.

These initiatives would require coherent educational planning, with close cooperation between MER's representatives at county level (Education directors), together with university and university college representatives including methodology TTs, as well as representatives from the municipalities on behalf of the schools. The summer courses and training of experienced teachers as teacher-as-trainers would need to be generously funded. In time, they could gradually replace the current centralised KK system as a new corps of expert English teachers and English teacher network coordinators develop localregional INSET training courses in collaboration with experienced methodology teacher trainers from selected regional university colleges or universities.

\section{Conclusion}

This study has compared different kinds of INSET courses. The results indicate the need to prioritise the development of primary school teachers' oral English speaking proficiency and methodological competence. While individual teachers are satisfied with the KK courses, the program is expensive and fails to systematically transfer knowledge to other teachers. The local course provides 
teachers with badly needed practical methodological input but does not help develop their speaking skills significantly and may not have long lasting effects without a network or mentors to provide follow-up. Above all, the vast disparity between the resources provided for the KK program and for the local "stop-gap" course reveals a lack of coherence in the educational planning of the training of English teachers in Norway.

The validity of the research is based on the presentation of significant facts and the comparison of a wide variety of perspectives and evidence, but is also limited by the relatively small size of the samples and the lack of availability of more detailed data. Nonetheless, to the extent that the findings appear credible and transferable, the proposals might be tested out using pilot projects and action research. Other research priorities include finding out precisely how many thousand primary school teachers currently teach English without formal training as language teachers, and to investigate which English subject teacher networks currently exist, and how they function.

Meanwhile, policy-makers should beware of underestimating the hunger and need for training amongst those currently struggling in the field of English teaching in primary schools, as expressed by the Head TT for the local course:

It was not about teaching them to fish - it was about them waiting like young puffins with open beaks to get a load of half-digested fish - lots of it.

A further question to consider is whether it is finally time to take preventative measures and make the "basic" subject of English, like the other "basic subjects" of Maths and Norwegian, an obligatory part of the teacher training of all future primary school teachers in Norway.

\section{Referencer}

Borg, S. (2006). The distinctive characteristics of foreign language teachers. Language Teaching Research, 10(1), 3-31.

Broad, K., \& Evans, M. (2006). A review of literature on professional development content and delivery modes for experienced teachers. Toronto: Canadian Ministry of Education.

Burns, A. \& Copland, F. \& Garton, S. (2011). Global practices in Teaching English to Young Learners. London: British Council.

Cohen L.,. \& Manion, L., \& Morrison, K. (2011). Research methods in education (7th Ed). New York: Routledge:

Cook, G., \& Hall, G. (2013). Own-language use in ELT: exploring global practices andattitudes. London: British Council.

Datta, L. (1997). Multimethod Evaluations: Using Case Studies Together With Other Methods. In Chelimsky, E., \& Shadish, W.R. Evaluation for the 21st century (pp. 344351). Thousand Oaks, California: Sage.

Darling-Hammond, L., \& Lieberman, A. (2012). Teacher education around the world: Changing policies and practices. London: Routledge

Enever, J. (Ed.) (2011). Early Language Learning in Europe. London: British Council. Eurydice (2012). Key data on teaching languages at school in Europe. European 
Commission: Eurostat.

Flick, U. (2007). Designing qualitative research. London: Sage.

Fullan, M., \& Hargreaves, A. (2002). Teacher Development and Educational Change. In Fullan, M.,.\& Hargreaves, A. (Eds.), Teacher Development and Educational Change (pp. 1-9). Routledge/Falmer Press: London.

Graves, K. (2009). The curriculum of second language teacher education. In Burns, A., \& Richards, J.C. (Eds.) The Cambridge Guide to Second Language Teacher Education. (pp. 115-124). Cambridge University Press: Cambridge.

Greene, J. (1995, November). "Evaluators as advocates“. Paper presented at the annual meeting of the American Evaluation Association, Vancouver.

Hayes, D., \& Chang, K. (2012). Theoretical Perspectives on and International Practice in Continuing Professional Development for English Teachers. English Teaching, 67, 107-129.

Johnson, K., \& Freeman, D. (1998). Reconceptualising the Knowledge-Base of Language Teacher Education. TESOL Quarterly, 32 (3), 397-417.

Joudenais, R. (2009). Language Teacher Education. In Long,M.H. \& Doughty, C.H. (Eds.) The Handbook for Language Teaching (pp. 647-658). Chichester: Wiley-Blackwell

Ju Youn Sim (2011). The impact of in-service teacher training. (Ph.D. Thesis), University of Warwick.

Kamhi-Stein, L, D. (2009). Teacher preparation and non-native speaking educators. In Burns, A., \& Richards, J.C. (Eds.) The Cambridge Guide to Second Language Teacher Education (pp. 91-102). Cambridge: Cambridge University Press.

Lagerstrøm, B,O. (2007). Kompetanse i grunnskolen. Oslo: Statistics Norway.

Lundberg, G. (2012, June). The Role of the Teacher in Early Language Learning. Conference paper, English for Young Learners. Forum 2012, Uppsala, Sweden

Mellegård, I. (2010, 11th March). Kompetanse for Kvalitet. Utdanning, pp. 48-51.

Ramboll (2012) Sammenfatning av skoleeieres rapportering på bruk av midler til etterog videreutdanning 2010. Oslo: Utdanningsdirektoratet.

Mujis, D., \& Lindsay, G. (2008). Where are we at? An empirical study of levels and methods of evaluating continuing professional development. British Educational Research Journal 34 (2), 195-211.

Gjerustad, C., \& Kårstein, A. (2013). Deltager undersøkelse. Kompetanse for Kvalitet (Rapport 35). Oslo: Nordisk institutt for studier av Innovasjon, Forskning og Utdanning.

Rasmussen, J., \& Klewe, L. (2012). Evaluering av nasjonal strategi for videreutdanning av lerere. Aarhus Universitet, Denmark: Oxford Research.

Stake, R.E. (1997). Advocacy in evaluation: A necessary evil? In Chelimsky, E. \& Shadish, W.R. Evaluation for the 21st century. (pp. 470-478). Thousand Oaks California: Sage.

Villegas-Reimers, E. (2003). Teacher professional development: an international review of the literature. UNESCO: International Institute for Educational Planning.

Waters, A., \& Vilches, M.L.C. (2010). 'Tanggap, tiklop, tago' (receive, fold, keep): Perceptions of best practice in ELT INSET. London: British Council. 